\title{
Equipe de enfermagem e comunicação: contribuições para o cuidado de enfermagem
}

\author{
Nursing staff and communication: contributions to nursing care \\ Equipo de enfermería y comunicación: contribución a la atención de enfermería
}

Submissão 22-12-2010 Aprovação: 06-03-2012

\section{RESUMO}

O objeto deste estudo é o processo de comunicação na equipe de enfermagem. A pesquisa é qualitativa e descritiva, cujo objetivo é identificar os elementos que compõem o processo de comunicação da equipe de enfermagem, analisar as estratégias de comunicação utilizadas pela equipe e discutir suas influências no cuidado de enfermagem. O referencial teórico aplicado é o modelo de processo de comunicação proposto por Berlo. As técnicas de produção dos dados foram a entrevista semiestruturada, com 25 profissionais de enfermagem, e a observação participante. Aos dados foram aplicadas as técnicas de análise de conteúdo temática. Para a equipe de enfermagem, a comunicação é uma forma de interação, um meio para o entendimento entre as pessoas e um instrumento para transmitir informações de modo verbal.

Descritores: Comunicação; Equipe de enfermagem; Cuidados de enfermagem.

\section{ABSTRACT}

The purpose is the communication process in nursing team. The research is qualitative and descriptive, whose aim is identify the elements that make up the communication process of the nursing team, to analyze the communication strategies used by the team and discuss their influence on nursing care. The theoretical model is applied to the communication process proposed by Berlo. Production techniques of data were semi-structured interviews with 25 nurses, and participant observation. The thematic content analysis was applied to the data. For nursing team, communication is a form of interaction, a means to understanding between people and a tool to convey information verbally.

Key words: Communication; Nursing staff; Nursing care.

\section{RESUMEN}

El objeto es el proceso de comunicación en el equipo de enfermería. La investigación es cualitativa y descriptiva, cuyo objetivo es identificar los elementos que componen el proceso de comunicación del equipo de enfermería, analizar las estrategias de comunicación utilizadas por el equipo y discutir sus influencias en la atención de enfermería. El referencial teórico aplicado es el de Berlo, en el cual se presenta un modelo de proceso de comunicación. Las técnicas de producción de datos fueron la entrevista semi-estructurada, con 25 profesionales de enfermería, y la observación participativa. A los datos han sido aplicadas las técnicas de análisis de contenido temático. Para el equipo de enfermería, la comunicación es un modo de interacción, un medio para el entendimiento entre las personas y un instrumento para transmitir informaciones de manera verbal.

Palabras clave: Comunicación; Equipo de enfermería; Atención de enfermería.

\section{AUTOR CORRESPONDENTE Priscilla Valladares Broca E-mail: priscillabroca@ig.com.br}




\section{INTRODUÇÃO}

A enfermagem tem como objetivo promover o cuidado que visa manter a saúde e a dignidade humana. Nesta perspectiva, para que o atendimento se alinhe à Política Nacional de Humanização ${ }^{(1)}$, há que se considerar o estabelecimento de vínculos, a construção de redes de cooperação e a participação coletiva no processo de gestão, e isso será possível quando entendermos a importância de valorizar os sujeitos envolvidos em tais redes.

Nesse sentido, a comunicação entre os profissionais, os gestores e os clientes configura-se em uma peça-chave, conforme estabelecido por uma das diretrizes desta política, a transversalidade ${ }^{(1)}$. Assim, a comunicação configura-se como um elemento essencial no cuidado. Entendida como o alicerce de nossas relações interpessoais, o cuidado, nesta perspectiva, associa-se à prática de comunicar-se. A comunicação, em suas variadas formas, tem um papel de instrumento de significância humanizadora e, para tal, a equipe precisa estar disposta e envolvida para estabelecer essa relação e entender que é primordial reconhecer o cliente como sujeito do cuidado e não passivo a ele.

Como forma de melhorar ou realizar o cuidado de enfermagem, destaca-se a importância do diálogo, pois através dele se cria uma aproximação entre as pessoas, inicia-se um contato mais próximo, uma relação de integração de culturas, uma troca de experiências e vivências ${ }^{(2)}$. Uma relação de comunicação eficiente entre todos os membros da equipe de enfermagem e da equipe multidisciplinar contribui para que as inter-relações profissionais estabelecidas no trabalho delimitem, melhor se a assistência ao paciente será ou não humanizada. E para que o processo de humanização seja efetivo, transformador e se realize, é imprescindível estreitar os laços de comunicação, de forma a desvendar e respeitar o ser profissional, favorecendo assim a compreensão contínua da realidade do paciente e do trabalhador ${ }^{(3)}$.

Assim, pode-se identificar e entender os problemas que lhe ocorrem e facilitar a interação profissional e pessoal, porque o homem se utiliza da comunicação em todos os momentos e ações de sua vida, e é por meio dela que se dividem as experiências e se pode modificar a si mesmo e o contexto em que se está inserido ${ }^{(4-8)}$. Desse modo, entender mecanismos de um processo de comunicação que irá auxiliar um desempenho melhor para com o cliente é tão importante quanto se empenhar para melhorar a comunicação, isto é, o relacionamento entre os próprios membros da equipe de enfermagem ${ }^{(5)}$.

À luz desse pensamento, identificar o processo de comunicação a partir de uma definição complexa, nas suas variadas formas e por ser um fenômeno que possui componentes específicos, de modo que busque melhorar a compreensão e a interação entre os partícipes da comunicação, se faz necessário para poder, de algum modo, contribuir com o relacionamento entre os indivíduos. Reforça-se a importância desse relacionamento entre trabalhadores que possuem o mesmo objetivo, quando se fala em assistência de enfermagem, ou seja, do cuidado.

Neste sentido, delimitou-se o objeto desta pesquisa como sendo o processo de comunicação na equipe de enfermagem, cujos objetivos foram: identificar os elementos que compõem o processo de comunicação na equipe de enfermagem; analisar as estratégias de comunicação utilizadas pela equipe de enfermagem e discutir suas influências no cuidado de enfermagem.

\section{REFERENCIAL TEÓRICO}

Esta pesquisa adotou Berlo ${ }^{(9)}$ como suporte para análise do processo comunicativo entre os membros da equipe de enfermagem, pois, para este autor, a comunicação é tudo aquilo que pode ser usado pelas pessoas, e que estas possam atribuir sentido. Há comunicação de várias formas, com muitas pessoas, por várias razões e em diferentes níveis. Além disso, a compreensão do processo, dos determinantes e das consequências da comunicação auxilia a capacidade básica do ser humano para enfrentar seus problemas de comunicação que surgem no trabalho, seja qual for ele.

Por se ter uma assistência de enfermagem envolvida com a arte e a ciência, que se apresenta de variadas formas, interativas ou não; e por existir vários elementos envolvidos na comunicação, elementos esses que permeiam a interação entre as pessoas, há necessidade de se ter uma comunicação dinâmica, contínua, ou seja, é preciso adotar a comunicação como um processo. Os acontecimentos e as relações são algo dinâmico, em evolução e sempre em mudança de forma contínua; de modo que é algo que não tem 'um' começo, 'um' fim, uma sequência fixa de eventos, não sendo algo parado, e sim algo móvel, onde cada um influencia o outro de alguma forma ${ }^{(9)}$.

Berlo apresenta um modelo de processo de comunicação no qual estão vários elementos inter-relacionados, sendo eles: a fonte, uma pessoa ou um grupo de pessoas com uma meta, um objetivo, uma razão para que haja uma comunicação; o codificador, efetuada pelas habilidades motoras da fonte (mecanismo vocal, o sistema muscular das mãos e os sistemas musculares de outras partes do corpo); a mensagem, a tradução de ideias, objetivos e intenções num código, num conjunto sistemático de símbolos; o canal, o intermediário, o condutor de mensagens; o decodificador, habilidades sensoriais e; o receptor, a outra pessoa na extremidade do canal.

\section{METODOLOGIA}

Esta pesquisa é de natureza qualitativa e descritiva. A coleta de dados foi realizada entre março e abril de 2010 e as técnicas de produção dos dados foram a entrevista semiestruturada, baseada em um roteiro com questões abertas, e a observação participante, com aplicação de um roteiro-guia, que foi realizada em dias alternados com as entrevistas de modo que se pudesse observar o processo de comunicação na equipe de enfermagem e, assim, retroalimentar o próprio processo da entrevista.

Foi utilizado um gravador digital para registrar as entrevistas, e as anotações oriundas das observações formaram um diário de campo, tendo como amparo teórico a descrição densa ${ }^{(10)}$. Ao corpus dos dados foram aplicadas as técnicas de análise de conteúdo temática ${ }^{(11)}$. 
Os sujeitos da pesquisa foram 25 profissionais que compõem a equipe de enfermagem e que atuam no setor de Clinica Médica e participam ativamente dos cuidados. Os critérios de inclusão dos sujeitos foram: serem enfermeiros, técnicos ou auxiliares de enfermagem, de ambos os sexos, serem integrantes das equipes de enfermagem do setor eleito para a pesquisa (desde que quisessem dela participar) e estar em efetiva atuação. Os critérios de exclusão foram: estar afastado do trabalho por qualquer motivo (férias, licença e outros) e não aceitar participar da pesquisa.

O cenário foi o setor de Clínica Médica de um hospital universitário, público e federal, que preconiza a aliança entre o ensino, a pesquisa científica e a assistência.

De acordo com o disposto na Resolução no 196/96 do Conselho Nacional de Saúde, os direitos dos sujeitos da pesquisa foram atendidos. O Projeto foi aprovado no Comitê de Ética em pesquisa do HUCFF/UFRJ, conforme o protocolo $\mathrm{n}^{\circ}$. 198/09. A identificação dos sujeitos foi feita por códigos alfanuméricos, em que a sigla $E$ significa enfermeiro, a sigla $T E$, técnico de enfermagem e a sigla $\mathrm{AE}$, auxiliar de enfermagem, e os números seguem a ordem de ocorrência das entrevistas.

\section{RESULTADOS E DISCUSSÃO}

\section{A comunicação como uma forma de interação social}

Para se comunicar não é preciso que as pessoas envolvidas no processo tenham algo em comum ou vivam numa mesma comunidade, ou por viverem numa mesma comunidade tenham algo em comum. A comunicação pode ser considerada, também, como um produto do encontro social, como ocorre na equipe de enfermagem.

Essa complexidade que é o processo comunicativo pode ser evidenciada nos dados da pesquisa, quando os sujeitos relatam que a comunicação se expressa de diversas formas, sendo algo muito amplo abrangendo muito mais que a própria fala.

É toda uma linguagem, não só de fala, mas de gesto, de tudo! É uma coisa muito ampla, comunicação! Ela não abrange só a fala, ela é muito ampla! E se a pessoa consegue fazer tudo isso, ela atende, atende a comunicação como um todo! (AE 3)

São todas as formas que eu tenho para me expressar com a outra pessoa. Isso que é comunicar! (TE 9)

Quando as pessoas se comunicam partilham experiências, pensamentos, impressões, conceitos e por meio dela podem modificar seus comportamentos e ajudar ao outro na construção de seu ser. Assim, compartilhar, transmitir, anunciar, trocar, reunir e ligar são expressões variantes ou usos figurados de um sentido primordial e mais geral que exprime relação(12), ou seja, há um quadro relacional.

Quando se relaciona com o outro, requer narrar, expor, descrever, travar conhecimento, conseguir fazer amizade e isso é possível quando se interage um com outro. Sendo assim, interação são ações e relações entre os membros de um grupo ou entre grupos de uma sociedade, sendo uma ação recíproca entre ambos ${ }^{(13)}$. Além disso, o trabalho de enfermagem tem como base as relações humanas, seja para com os clientes seja com a equipe e por causa disso o processo de comunicação é primordial para se estabelecer essa interação(5).

No processo de comunicação, a fonte e o receptor se influenciam mutuamente e cada um é em parte criado pelo outro, o que causa uma relação de interdependência entre ambos, onde o nível mais complexo dessa relação é a interação. A interação é quando dois indivíduos tiram inferências sobre os próprios papéis e assumem o papel um do outro ao mesmo tempo, e se o seu comportamento de comunicação depende da adoção recíproca de papéis, então eles estão em comunicação $^{(9)}$. Nessa ideia, os profissionais da equipe de enfermagem relataram que se comunicar com alguém é estar interagindo com outra(s) pessoa(s) e com o meio.

É interagir... .com uma pessoa, com várias pessoas. (TE 3)

Ah... é interagir! É interagir com a equipe, com as pessoas, ter um bom relacionamento! (TE 11)

Quando estamos interagindo buscamos interpretar os acontecimentos, expor as implicações de um evento e falar sobre ele e como ele interfere em um outro evento, deduzir por meio do raciocínio as conclusões do desconhecido e fazer previsões sobre o futuro, sendo de um evento próprio da pessoa ou da outra com quem se relaciona, ou seja, quer dar um determinado significado de um evento para o receptor. A partir disso, podem-se fazer previsões não verdadeiras um do outro, e com isso tentar mudar essas inverdades com argumentações de modo a influenciar o comportamento dos partícipes da comunicação.

Assim, na interação, os atores da comunicação estão inter-relacionados um com o outro, na tentativa de conjugar dois organismos, de cobrir a lacuna entre indivíduos pela produção e recepção de mensagens que tenham sentido para ambos; essa é a tarefa que a comunicação interativa busca ${ }^{(9)}$. A partir disso, pode-se dizer que o objetivo da comunicação é a interação.

A importância da interação entre os profissionais de saúde é visto como um desafio pela Política Nacional de Humanização, para que se possa produzir saúde e de forma qualificada, pois a humanização traz a melhora da interação nas equipes e a qualificação delas como uma forma de conseguir melhor lidar com as singularidades dos sujeitos e coletivos na prática de atenção a saúde ${ }^{(1)}$. Assim, qualificar o processo de comunicação na equipe de enfermagem é uma importante estratégia para que se possa prestar uma assistência ao cliente de forma efetiva e com maior eficácia.

Partindo dessas ideias, verifica-se que a maneira de agir da fonte não ocorre independentemente da maneira de agir do receptor, ou a maneira de agir do receptor não ocorre independentemente da maneira de agir da fonte, ou seja, fonte e receptor são interdependentes em qualquer modo de comunicação. A interdependência pode ser definida como a dependência "recíproca" ou "mutua" entre a fonte e o receptor, 
como por exemplo, se A influencia B e B influencia A, consequentemente $\mathrm{A}$ e B são interdependentes ${ }^{(9)}$.

O enfermeiro precisa planejar, organizar, coordenar, executar e avaliar os serviços da assistência de enfermagem, de acordo com que rege a lei do exercício profissional, para que se efetive o cuidado. Dessa forma, o trabalho da equipe de enfermagem pode ser considerado interdependente, pois os eventos referentes às ações de enfermagem, isto é, o cuidado de enfermagem, necessita da integração entre todos os profissionais. Assim, a comunicação é uma importante aliada para facilitar essa integração e consequentemente auxiliar no cuidado.

A importância dessa relação de interdependência na equipe de enfermagem e do seu resultado em termos de cuidado integral pode ser observada em alguns dados gerados nas entrevistas, quando os sujeitos informam que a comunicação é a base do trabalho que executam, sendo "tudo" na área da saúde, pois qualquer situação ocorrida que não é transmitida para o outro membro da equipe ou uma comunicação falha, pode ocasionar um entendimento equivocado entre os profissionais e até mesmo afetar o cliente, prejudicando seu tratamento e recuperação.

Se comunicar com alguém é a base de tudo, porque sem comunicação como a gente vai... desempenhar todo o nosso trabalho?! A gente tem que ... é ... comunicar da melhor forma possível, porque qualquer coisa que a gente deixa passar... uma falha na comunicação ocorre mil e uma coisa! Mal entendido, mal entendimento, deixa passar, uma expressão... e às vezes até o seu gesto [...] afeta muito na questão de você com o paciente! E você com a equipe também! (AE 4)

[...] você tem que manter uma comunicação, ainda mais no meio em que nós trabalhamos, na área da saúde, sempre tem que ter uma comunicação um com o outro. [...] se estão dois no plantão na mesma enfermaria, tem que ter comunicação pra saber o que um fez no paciente, pro outro não repetir o mesmo procedimento, então comunicação na área da saúde é tudo! (TE 12)

Destaca-se que a interdependência da equipe de enfermagem é do nível de ação e reação, ou seja, cada integrante do processo comunicativo envia a mensagem, a recebe e reage a essas mensagens ${ }^{(9)}$. Ao comunicar tem-se um objetivo, que é colocado em ação quando se inicia esse processo e espera-se um resultado do outro com quem comunicamos: a reação. É o feedback.

Assim, o feedback proporciona "à fonte informação referente ao seu sucesso na realização de um objetivo e, ao fazer isso, exerce controle sobre futuras mensagens que a fonte venha a codificar" ${ }^{\prime(9)}$. Ele envolve a revelação ao outro o que o seu comportamento causa em termos de pensamentos e emoções, ou seja, consiste em solicitar e estar aberto para receber as reações dos outros, em termos de pensamentos e emoções demonstrados de maneira verbal e não-verbal ${ }^{(5)}$. E isso facilita no comportamento efetivo com o outro.
Logo, a fonte pode usar o feedback como uma forma de determinar se houve êxito na sua comunicação, pois a reação do receptor servirá como verificação de sua própria eficiência como fonte e também poderá ser um guia para suas outras relações de comunicação futuras, porque dependendo da reação do receptor, a fonte poderá repetir o modo como transmitiu a mensagem para obter um mesmo feedback efetivo para com outra mensagem emitida com outro receptor.

Na equipe de enfermagem, o feedback é muito importante para verificar se alguma informação transmitida para os membros da equipe está sendo compensadora ${ }^{(9)}$. Como por exemplo, o feedback serve para avaliar as mensagens transmitidas sobre como agir num determinado procedimento ou até mesmo se as prescrições de enfermagem estão sendo realizadas de forma efetiva, pois conforme for o resultado dos receptores a fonte precisará efetuar mudanças no seu modo de enviar a mensagem ou até mesmo mudar o conteúdo da mesma.

A importância do feedback também pode ser observada quando os profissionais relataram que às vezes não se recebe a resposta que se espera, ou por falha da fonte ou pelo receptor não querer ouvir. E, também, porque para alcançar o objetivo da comunicação é preciso ter uma resposta positiva, através do entendimento da mensagem pelo receptor.

Pra que a comunicação alcance o seu objetivo, é necessário um feedback! Não adianta se o outro não quer te entender naquele momento, se ele não estiver disposto a... entender o que você quer passar pra ele; ele vai te ouvir, mas não vai entender. (TE 2)

Geralmente eu faço um feedback para ver se a pessoa entendeu o que eu quis passar. Pergunto se a pessoa entendeu, peço até para repetir, para ver mesmo se a pessoa entendeu o que eu quis passar. Ou [...] então eu vejo através do resultado. (TE 3)

A respeito disso, o feedback pode funcionar como indicador de parabenização para com o receptor e dessa forma influenciá-lo a ter sempre reações positivas, pois às vezes esquece-se de parabenizar as pessoas quando elas fazem um bom trabalho. Esta atitude pode influenciar as pessoas a terem reações futuras positivas para com a fonte. Além disso, o conhecimento obtido por essa comunicação positiva poderá servir de base para outra relação comunicacional efetiva.

De um modo geral, os seres humanos gostam de ser elogiados, e ter seus atos, trabalhos ou talentos reconhecidos. Assim, os profissionais de enfermagem querem ser valorizados e reconhecidos pelo seu trabalho, como já indicado em outro resultado de pesquisas ${ }^{(14)}$, dessa forma é preciso lançar mão da estratégia de investir no profissional de enfermagem, nem que seja através da comunicação escrita.

Hum ... é ... teve assim, por carta, eu já fui chefia desse posto, aí no tempo era surto de tanta bactéria, tanta bactéria, aí, eu com o pessoal, orientando:"- Olha, vamos fazer isso, vamos fazer aquilo!", e tentava puxar a equipe, eu caia dentro com a equipe, aí tá! Aí, depois veio uma carta, 
é... falando do meu trabalho, falando, do posto que superou as bactérias que tinham, que (risos) só elogios! (risos) Foi muito bom, foi muito bom! (E 4).

Assim, a interação tem um grande papel na equipe de enfermagem de modo a aumentar a nossa capacidade de influenciar e ser influenciados quando se participa de um processo de comunicação e, dessa forma, favorecer o desenvolvimento de um cuidado efetivo para com o cliente. $O$ ideal de uma comunicação, a meta de uma comunicação é a interação entre fonte e receptor ${ }^{(9)}$ e a comunicação interpessoal ocorre no contexto da interação face a face ${ }^{(5)}$. Mas nem toda comunicação consegue ser interativa, pois o ser humano sofre constantemente com fatores que interferem no processo comunicativo que o torna efetivo ou não.

\section{A comunicação como uma forma de entender o outro e se fazer entender}

Ao se comunicar o ser humano tem uma expectativa em relação a esse processo. Essa expectativa é de como será dada a resposta pelo receptor, isso em relação à fonte, mas o receptor também tem a sua expectativa em relação à fonte sobre o tipo de mensagem que essa fonte irá produzir e se ele poderá tirar algum proveito dessa relação (mensagem). Essa relação existe porque se criam expectativas que influenciam as ações, antes mesmo de executá-las, ou seja, espera que o receptor tenha a capacidade, ou pelo menos tente, de assimilar corretamente a mensagem transmitida. Além disso, a comunicação é uma via de mão dupla, ou seja, é necessário que haja resposta e validação da mensagem ocorrida ${ }^{(5)}$, o que na visão dos profissionais é entender o outro e ser entendido. E essa expectativa pode ser alcançada pelo entendimento, como se observa nesses depoimentos:

Eu acho que é me fazer ser entendida e entender o outro! É comunicar. (TE1)

É ... se fazer entender, primeiro com a pessoa e você entender também essa pessoa para qual você está entrando em contato, está entrando em comunicação. Então, desde o momento que você se faz entender e entende o outro, você está se comunicando. (TE 2)

Ser entendido ou entender o outro, significa apreender o significado de um símbolo, a força de um argumento, o valor de uma ação ${ }^{(15)}$. E essa ação pode ser compreendida como a comunicação. Assim, tenta-se assimilar mentalmente o que a comunicação exprime na possibilidade de estabelecer corretamente o que está sendo posto pela fonte e pelo receptor e ter a capacidade de tornar as coisas mais claras e explícitas e diminuir a possibilidade de realizar uma tradução e interpretação errônea. Por isso, é importante não confundir os conceitos das palavras e muito menos o meio que a comunicação ocorre, o sentimento, a ideia e o juízo da pessoa atribuídos a esse processo.

Além disso, é preciso haver uma entrega de si quando se participa de um processo comunicativo para que se tenha a possibilidade de entender os motivos, os sentimentos, as angústias, os significados e as particularidades de cada individuo envolvido, e, dessa forma, se concordar ou não com a mensagem e também questioná-la. Quando alguém passa ou passou pela mesma situação do outro fica mais fácil entendê-lo do que quando não se teve as mesmas experiências. E a partir disso é possível construir trocas solidárias que sejam comprometidas entre os profissionais com o objetivo de produzir saúde e sujeitos ${ }^{(1)}$.

A fonte tem um objetivo ao iniciar o processo de comunicação, ou seja, ele quer produzir algum efeito no receptor ${ }^{(9)}$. E uma das finalidades básicas da comunicação é entender o mundo, se relacionar com o outro e transformar a si mesmo e ao outro ${ }^{(5)}$. Assim, a fonte quer que o outro tenha um comportamento que seja favorável, que irá produzir aquilo esperado por ele. E ao mesmo tempo o receptor quer ser recompensado pela sua comunicação, pela sua informação transmitida, ou seja, a fonte quer ser entendida e o receptor quer entender o outro.

Desse modo, a fonte pode ter um "objetivo consumatório", ou "objetivo instrumental", isto é, os indivíduos envolvidos no processo comunicativo podem ser recompensados imediatamente ou não ao produzirem certos tipos de mensagens ${ }^{(9)}$. Por exemplo, no "objetivo consumatório", a pessoa ao ler, assistir algo, conversar ao acaso, espera ser recompensado de imediato de forma a se sentir satisfeito consigo mesmo, de relaxar ou reduzir tensões; já no "objetivo instrumental", a pessoa pode ler sobre algo a fim de poder contar aos outros sobre ela mais tarde e ser considerado o "sabe tudo" ou "o bem informado"(9) e com isso receber méritos pela sua comunicação.

Assim, quando o profissional de enfermagem diz que quer ser entendido e também entender o outro pode ter esses dois objetivos, pois ele quer receber a recompensa imediata de ser entendido ou o mérito de ser reconhecido como o que entende a todos e a tudo e, assim, ser considerado o "sabe tudo". Entender tudo e a todos é difícil, porque não se conhece todas as coisas do mundo e, além disso, as pessoas a cada dia recebem influencias do ambiente que o cerca e com isso a cada dia amadurecem.

\section{As diversas faces da comunicação na equipe de enferma-} gem: A comunicação verbal da equipe de enfermagem

Uma pesquisa demonstrou que uma pessoa comum gasta cerca de $70 \%$ do seu tempo ativo comunicando-se verbalmente, seja ouvindo, falando, lendo ou escrevendo, isto é, "cada um de nós gasta de 10 a 12 horas por dia, todos os dias se comunicando de forma verbal" ${ }^{(9)}$. Dessa forma, a comunicação verbal é muito importante para a convivência dos indivíduos, pois a partir dela as relações de interação são possíveis, mas a não verbal também tem o seu papel nessa relação.

A comunicação verbal refere-se à linguagem escrita e falada, aos sons e palavras que são usadas para comunicar ${ }^{(4-5)}$. O uso da linguagem é o recurso com o qual as pessoas compartiIham suas ideias, experiências e pode-se validar o significado simbólico da percepção sobre o assunto e o lugar que se ocupa nele, além de confirmar aquilo que expressa através da comunicação não verbal e, assim, clarificar a pessoa quanto à informação transmitida de modo a ser entendido corretamente.

Para que uma comunicação verbal seja bem sucedida é preciso que se tenha clareza nas mensagens transmitidas e para 
que isso ocorra é necessário ter uma linguagem, escrita ou falada, que seja compatível entre os indivíduos envolvidos no processo, além de terem um patamar intelectual parecido ou igual, pois é imprescindível que haja entendimento entre quem ouve ou lê para que o processo comunicativo seja efetivo.

Os resultados da pesquisa em tela mostraram que a equipe de enfermagem, majoritariamente, considera que o processo comunicativo se dá através da forma verbal, seja ela falada ou escrita. Na equipe de enfermagem essa comunicação é feita por sentar e conversar a qualquer hora no decorrer do plantão ou através da passagem de plantão.

A comunicação é verbal e algumas coisas também é escrita! (AE 2)

É ... assim... eu converso com as meninas, as meninas entendem o que eu falo, e... expõem o que elas entenderam, se elas não entenderam perguntam de novo [...] ( E 4)

Pode ser verbal é ... comunicação verbal através de passagem de plantão [...] (E 1)

O ato de falar é considerado defeituoso quando a comunicação não é efetiva, talvez porque a maneira de falar possa distrair a atenção sobre o que é dito ou por constrangimento da fonte diante da sua dificuldade de falar ou por timide $z^{(5)}$. Para se ter uma boa comunicação e facilitar a assistência de enfermagem aos clientes, a equipe se utiliza da estratégia da comunicação verbal. Quando estão dois ou mais profissionais responsáveis por uma mesma enfermaria, eles costumam confirmar um com o outro o que foi feito pelo cliente em relação à assistência, para que não se repita, por exemplo, uma medicação.

[...] principalmente quando você tá assim trabalhando junto com um colega numa enfermaria, tem que ter uma boa comunicação, porque às vezes ela pode pensar assim: “- Ah... você fez tal medicamento!" e eu posso pensar: "-Ah.... foi ela que fez!", então, tá sempre perguntado:"- Você já fez isso? Vamos fazer junto? Agora, vamos fazer o que?". Tudo assim, dentro junto, numa boa interação! (AE 4)

\section{Reuniões e o reservado individual como forma de se co- municar na equipe de enfermagem}

Reunião é a ação ou efeito de reunir ou reunir-se, isto é, um conjunto de pessoas que se agrupam para algum fim ${ }^{(13)}$. Ela é um momento importante para um grupo, pois é através dela que se pode partilhar informações, emoções e sentimentos; discutir; crescer e amadurecer em conjunto e assim facilitar as pessoas a enfrentarem a realidade em que vivem além de proporcionar aprendizagem e comunicação.

Os resultados da pesquisa mostram que, quando os profissionais querem transmitir uma mensagem para a equipe, lançam mão da reunião. Mas eles só se utilizam dessa estratégia quando o assunto é comum a todos, pois quando o assunto envolve somente um único membro, como por exemplo, quando se quer chamar a atenção de alguém que fez algo errado, ocorre uma conversa reservada. Na observação de campo foi possível identificar que tais conversas reservadas ocorrem na própria sala da chefia de enfermagem, que fica no posto, ou na sala de exame, que se localiza próximo ao posto de enfermagem e que somente é utilizada em situações especiais de exames dos clientes, quando há necessidade de maior privacidade.

Como ... vou colocar aqui umas colocações: caso eu veja que aquele problema é com um, eu vou naquele um, reservado e converso. Se é uma comunicação eu possa passar no geral, eu passo ... eu chamo todo mundo e passo! (E 2)

Quando é uma coisa individual, a gente chega perto da pessoa e fala mesmo, entendeu?! Não tem necessidade de você abrir pra outras pessoas uma coisa que é só com aquela pessoa. Só quando for, assim, uma coisa de forma geral, que tem que alertar de forma geral a gente junta as pessoas. (TE 8)

Observa-se, neste ínterim, o cuidado que se tem com a privacidade alheia, evitando-se a exposição desnecessária e até mesmo a humilhação, caracterizando-se o aspecto ético que envolve a interação: o respeito ao outro.

No que se refere ao processo comunicativo propriamente dito, as pessoas envolvidas podem ter determinados objetivos: informar, persuadir ou divertir ${ }^{(9)}$. Entende-se que um processo é persuasivo quando a meta principal da comunicação é levar a outra pessoa a adotar o ponto de vista de quem fala; o objetivo informativo é alcançado quando se dissemina uma informação, notícia que se intenta levar ao conhecimento de todos; já a diversão ocorre quando a comunicação tem cunho de distração ou passatempo.

Algumas das reuniões e conversas entre os membros observadas na equipe de enfermagem tinham como objetivo a persuasão, quando se queria que membros da equipe adotassem uma nova postura, e também a informação, principalmente quando se relacionava às situações dos clientes ou questões ligadas à instituição. Por exemplo, numa passagem de plantão uma enfermeira se utilizou da persuasão, ao pedir que a equipe não usasse mais o nome "jontex" nos registros das evoluções no prontuário quando o cliente estava em uso deste artefato, mas que escrevessem "dispositivo para coletor de urina aberto". Em outra passagem de plantão, a enfermeira chefe se utilizou do objetivo informativo da comunicação, ao levar ao conhecimento de toda a equipe que entraria de férias no mês seguinte e que outra enfermeira ficaria no seu lugar, respondendo pelo plantão.

\section{CONCLUSÕES}

Nesta pesquisa, pode-se identificar que o processo de comunicação da equipe de enfermagem evidenciou-se como sendo todas as formas de se expressar com o outro, sendo compreendido como algo muito mais que simplesmente falar - algo complexo e imprescindível. A interação emergiu dos dados como sendo um dos objetivos da comunicação de modo que os participes do processo tem como meta influenciar o 
outro com quem se relaciona. E com isso há uma relação de interdependência, ou seja, fonte influencia receptor e receptor influencia fonte. E essa influencia, na equipe de enfermagem, pode ser utilizada para que a assistência de enfermagem possa ser realizada de forma eficaz, pois se cria uma parceria entre eles para alcançar o cuidado de enfermagem.

Só há comunicação se dois indivíduos participam ativamente do processo, e essa relação poderá facilitar a prática da humanização, pois é um modo de qualificar o relacionamento entre os profissionais. A comunicação tem seu alicerce nas relações interpessoais que se configura a partir da interação, e a enfermagem, ciência e arte de cuidar, se dá no campo da interação humana.

No ato de se comunicar, temos de fazer previsões sobre como a outra pessoa comportar-se-á, criam-se expectativas ou previsões dos outros e de nós mesmo. Podem-se desenvolver essas expectativas ou previsões pelo aperfeiçoamento de nossa capacidade em se colocar no lugar do outro e de nossa capacidade de projetar-nos na personalidade do outro, tendo como objetivo a interação. Assim, a adoção de papéis e a interação são instrumentos úteis para melhorar a eficiência da comunicação. Mas para que isso ocorra precisa haver motivação para tal.

Quando se tem a tendência de interpretar o mundo apenas pelo nosso ponto de vista, torna-se difícil a interação e, consequentemente, uma simples comunicação. Portanto, entender o outro e ser entendido por este emergiu dos depoimentos como sendo um dos objetivos do processo de comunicação, pois através desse entendimento mútuo há maior possibilidade em tornar a comunicação efetiva e, com isso, aumenta-se a possibilidade de se co-construir e se comprometer juntos com o cuidado de enfermagem.

A comunicação verbal também emergiu como sendo o tipo de comunicação mais utilizado pelos profissionais de enfermagem no decorrer do dia de trabalho, e essa comunicação tem cunho informativo sendo largamente utilizada nas reuniões para se discutir as situações dos clientes ou assuntos de interesse comum. A estratégia da conversa reservada mostrou amadurecimento e respeito mútuo entre a equipe, evidenciando o caráter ético que permeia a comunicação.

Desse modo, os resultados desta pesquisa apontaram que o processo de comunicação entre os membros da equipe de enfermagem é otimizado em função do cuidado ao cliente, através da interação humana; relação de interdependência; reconhecimento profissional; melhora do entendimento do outro; compartilhamento de informações através de reuniões em grupo, quando os assuntos couberem a todos da equipe, e conversas individuais e reservadas quando assim as situações vivenciadas pelos membros da equipe requerer.

\section{REFERÊNCIAS}

1. Ministério da Saúde (Brasil) Secretaria de Atenção à Saúde, Núcleo Técnico da Política Nacional de Humanização. Humaniza SUS: documento base para gestores e trabalhadores do SUS. 4. ed. Brasília: Ministério da Saúde, 2008.

2. Barra DCC, Waterkemper R, Kempfer SS, Carraro TE, Radünz V. Hospitalidade como expressão do cuidado em enfermagem. Rev Bras Enferm 2010;63(2):203-8.

3. Backes DS, Lunardi VL, Lunardi FWD. A humanização hospitalar como expressão da ética. Rev Latinoam Enferm 2006;14(1):132-5.

4. Stefanelli MC. Comunicação com paciente: teoria e ensino. $2^{\circ}$ ed.. São Paulo: Robe Editorial; 1993.

5. Silva MJP. Comunicação tem remédio: a comunicação nas relações interpessoais em saúde. $4^{\text {a }}$ ed. São Paulo: Loyola; 2006.

6. Tigulini RS, Melo MRAC. A comunicação entre enfermeiro, família e paciente crítico. Anais do $8^{\circ}$ Simpósio Brasileiro de Comunicação em Enfermagem [evento na internet] 2002 Out; São Paulo, Brasil [acesso em 04 jul 2009]. Disponível em: http://www.proceedings.scielo.br/scielo.ph p?pid = MSC00000052002000200047\&script = sci_arttext.

7. Oliveira MMC, Almeida CB, Araújo TL, Galvão MTG. Aplicação do processo de relação interpessoal de Travelbee com mãe de recém - nascido internado em uma unidade neonatal. Rev Esc Enferm USP 2005; 39(4):430-6.
8. Barlem ELD, Rosenhein DPN, Lunardi VL, Lunardi Filho WD. Comunicação como instrumento de humanização do cuidado de enfermagem: experiências em unidade de terapia intensiva. Rev. Eletr. Enf. [periódico online]. 2008 Ago-Out. [acesso em 04 abril 2009];10(4):10419. Disponível em: http://www.fen.ufg.br/revista/v10/n4/ v10n4a16.htm.

9. Berlo DK. O processo da comunicação: introdução à teoria e à prática. 10ª ed. São Paulo: Martins Fontes; 2003.

10. Geertz C. A interpretação das culturas. Rio de Janeiro: Livros Técnicos e Científicos; 1989.

11. Bardin L. Análise de Conteúdo. $7^{\mathrm{a}}$ ed. Lisboa: Editora 70; 1979.

12. Martinho LC. De qual comunicação estamos falando? In: Hohlfeldt, A; Martino, LC; França, VV, organizadores. Teorias da comunicação: Conceitos, escolas e tendências. 9a ed. Rio de Janeiro: Vozes; 2010. p. 11-25.

13. Michaelis. Moderno dicionário da língua portuguesa. São Paulo: Editora Melhoramentos; 2007.

14. Bezerra FD, Andrade MFC, Andrade de JS, Vieira MJ, Pimentel D. Motivação da equipe e estratégias motivacionais adotadas pelo enfermeiro. Rev Bras Enferm 2010;63(1):33-7.

15. Abbagnano N. Dicionário de filosofia. $5^{\mathrm{a}}$ ed. São Paulo: Martins Fontes; 2007. 